\title{
Helicopter Crash Frequency
}

by

M. D. Brandyberry

Westinghouse Savannah River Company

Savannah River Site

Aiken, South Carolina 29808

\section{RECEIVED}

JUN 111998

OSTI

DOE Contract No. DE-AC09-89SR18035

This paper was prepared in connection with work done under the above contract number with the U.S.

Department of Energy. By acceptance of this paper, the publisher and/or recipient acknowledges the U.S. Government's right to retain a nonexclusive, royalty-free license in and to any copyright covering this paper, along with the right to reproduce and to authorize others to reproduce all or part of the copyrighted paper.

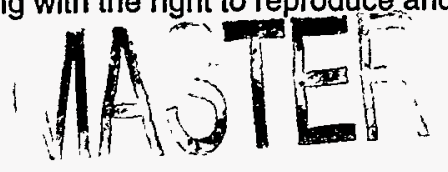






d



\section{DISCLAMMER}

This report was prepared as an account of work sponsored by an agency of the United States Government. Neither the United States Government nor any agency thereof, nor any of their employees, makes any warranty, express or implied, or assumes any legal liability or responsibility for the accuracy, completeness, or usefulness of any information, apparatus, product, or process disclosed, or represents that its use would not infringe privately owned rights. Reference herein to any specific commercial product, process, or service by trade name, trademark, manufacturer, or otherwise does not necessarily constitute or imply its endorsement, recommendation, or favoring by the United States Government or any agency thereof. The views and opinions of authors expressed herein do not necessarily state or reflect those of the United States Government or any agency thereof.

This report has been reproduced directly from the best available copy.

Available to DOE and DOE contractors from the Office of Scientific and Technical Information, P.O. Box 62, Oak Ridge, TN 37831; prices available from (615) 576-8401.

Available to the public from the National Technical Information Service, U.S. Department of Commerce; 5285 Port Royal Road, Springfield, VA 22161.

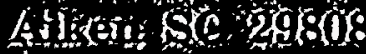



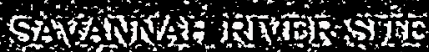




\section{DISCLAIMER}

Portions of this document may be illegible electronic image products. Images are produced from the best available original document. 
Helicopters

Wackenhut

Reactor

Safety

Accident

Aircraft

Retention: Lifetime

\section{ANALYSIS OF THE IMPACT OF SRS HELICOPTER OPERATIONS ON REACTOR SAFETY(U)}

by

M.D. Brandyberry

Issued: March 1990

$S R L$

SAVANNAH RIVER LABORATORY, AIKEN, SC : 29808

W estinghouse Savannah River Company

Savannah River Site

Aiken, SC 29808

PREPARED FOR THE U.S. DEPARTMENT OF ENERGY UNDER CONTRACT NO. DE-AC09-88SR18035




Document:

Title:

Revision Number:
WSRC-TR-90-90

ANALYSIS OF THE IMPACT OF SRS HELICOPTER OPERATIONS ON REACTOR SAFETY

0

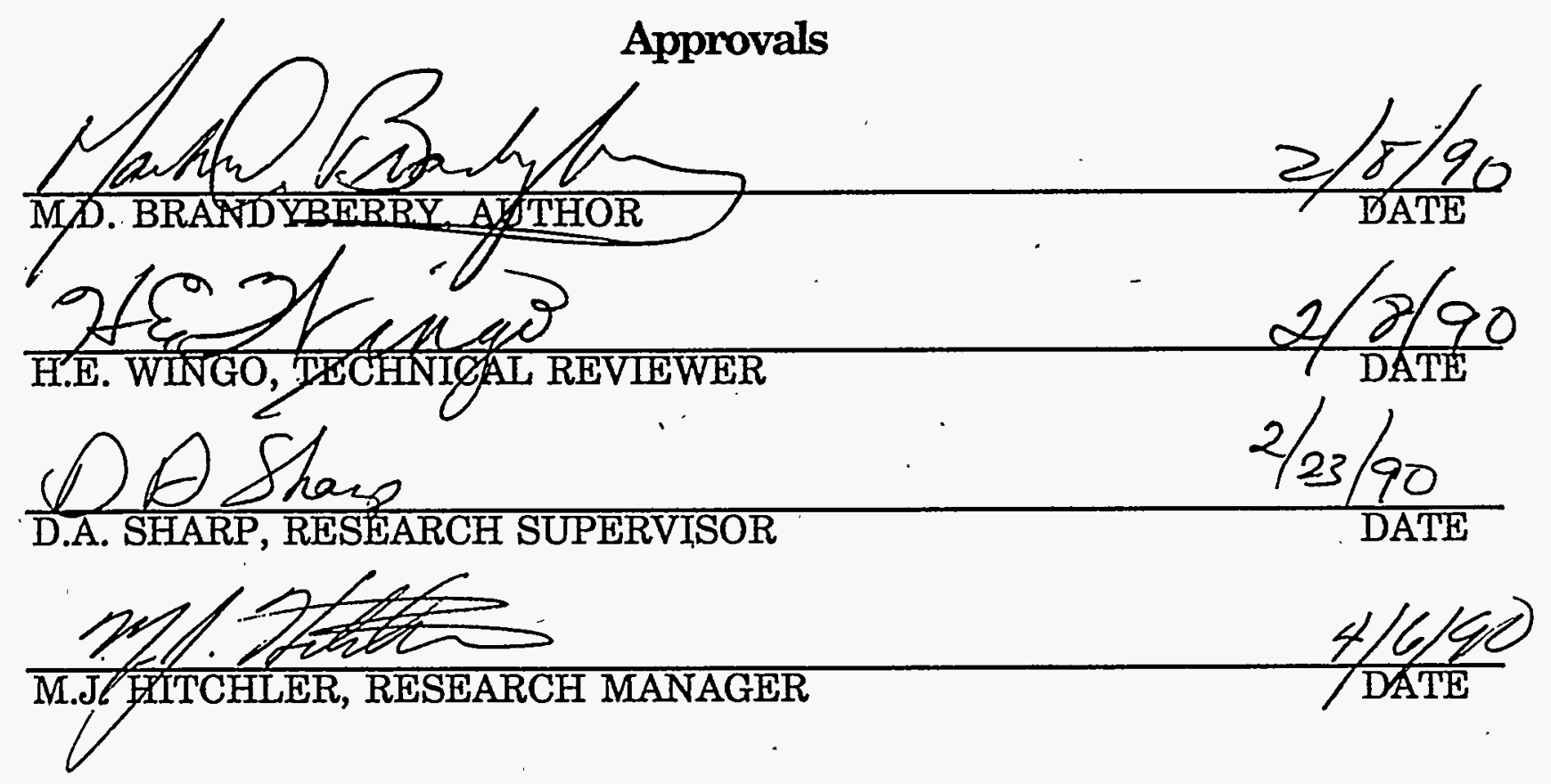


WSRC-TR-90-90

\section{ANALYSIS OF THE IMPACT OF SRS HELICOPTER OPERATIONS ON REACTOR SAFETY}

\section{HELICOPTER CRASH}

The risk from helicopter crashes into K-reactor structures and systems is found to be a negligible contributor to risk, as described below.

\section{AIR TRAFFIC SOURCES AND PATHWAYS}

Except for the Wackenhut service, Inc. (WSI) helicopter pad, there are no airports within 10 miles of $\mathrm{K}$-reactor. The risk from aircraft operations from these distant airports are assessed in Reference [1] and will not be repeated here.

WSI operates a helicopter pad on the SRS. It is located in the western portion of the site, and K-reactor is about 6.5 miles to the southeast of the heliport. Two lightweight, multipurpose helicopters are operated by WSI to provide aviation support to the security support services [2]. These helicopters are both Model BK117A3 manufactured by the MBB Helicopter Corp. of Westchester, PA. They are twin engine machines with a maximum gross flying weight of approximately $7000 \mathrm{lbs}$., a maximum airspeed of $149 \mathrm{mph}$, and a maximum fuel load of 183 gallons. These aircraft are generally operated with two pilots.

\section{PROBABIITY OF HELICOPTER CRASHES}

As discussed in [1] the probability of an aircraft crashing can be separated into two regimes: aircraft takeoff and landing, and normal flight. Reference [3] gives the probability of an aircraft crash per square mile per aircraft movement for different distances from the runway (See Table 1).

Statistics on helicopter flights at the SRS, however, are only available in the form of flight hours per aircraft categorized by class of mission flown. Examples of the mission classes categorized are routine patrols, training and practice exercises; maintenance and miscellaneous. Of these categories, training, routine patrols and practice exercises encompass the vast majority of the hours flown at the SRS.

It is somewhat more difficult, however, to assess where on site these flight hours actually occur. Total helicopter flight hours for WSI helicopters at the SRS were 814.2 hours in FY 1988 and 715.9 hours in FY 1989. Discussions with helicopter operations personnel [4] indicate that the current inactive state of the reactors have little effect on their operations, and thus, these totals should be indicative of the actual number of flight hours that can be expected on site in any given year. These totals, however, include time from all helicopter activities on all areas of the site. The majority of these flight hours are flown nowhere near the reactor areas and thus pose no risk to reactor operation. In an attempt to assess the proportion of the total flight hours that are spent near the reactor areas, helicopter operations personnel attempted to assess percentages of missions in each category in which the flight paths of the aircraft would 


\begin{tabular}{|c|c|c|c|c|}
\hline \multirow{2}{*}{$\begin{array}{l}\text { Distance } \\
\text { from end of } \\
\text { runway } \\
\text { (miles) }\end{array}$} & \multicolumn{4}{|c|}{$\begin{array}{c}\text { Probability }\left(\mathrm{x} 10^{8}\right) \text { of a fatal crash per square mile } \\
\text { per aircraft movement }\end{array}$} \\
\hline & $\begin{array}{l}\text { U.S. Air } \\
\text { Carrier }\end{array}$ & $\begin{array}{l}\text { General } \\
\text { Aviation }\end{array}$ & USN/USMC & USAF \\
\hline$\overline{0-1}$ & 16.7 & 84.0 & 8.3 & 5.7 \\
\hline $1-2$ & 4.0 & $\overline{15.0}$ & 1.1 & 2.3 \\
\hline 23 & 0.96 & 6.2 & 0.33 & 1.1 \\
\hline $3-4$ & 0.68 & 3.8 & 0.31 & 0.42 \\
\hline $4-5$ & 0.27 & 1.2 & 0.20 & 0.40 \\
\hline $5-6$ & 0.0 & $\overline{\mathrm{NA}}$ & $\overline{\mathrm{NA}}$ & $\overline{\mathrm{NA}}$ \\
\hline $6-7$ & 0.0 & $\mathrm{NA}$ & $\overline{\mathrm{NA}}$ & $\overline{\mathrm{NA}}$ \\
\hline $7-8$ & 0.0 & $\overline{\mathrm{NA}}$ & $\overline{\mathrm{NA}}$ & $\overline{\mathrm{NA}}$ \\
\hline $8-9$ & 0.14 & NA & NA & NA \\
\hline $9-10$ & 0.12 & $\overline{\mathrm{NA}}$ & $\overline{\mathrm{NA}}$ & $\mathrm{NA}$ \\
\hline
\end{tabular}

NA indicates that data was not available for this distance

Table 7.1 Distribution of airplane crashes per square mile [3]

terminate at or pass by reactor areas. These estimates are necessarily approximate, however, we can gain useful insight from them.

Four of the categories, routine patrols, shipment escorts, training, and practice exercises, involve the possibility of flying near a reactor area. Of the routine patrol category, it is estimated that the flight paths are rarely near the reactor areas and therefore only a few percent of the routine patrol flight hours are spent near the reactors. One leg of shipment escorts always terminates near a reactor area. For training and practice exercises, the percentage of time spent near the reactor areas is very dependent on the type of training. In 1988 there was substantial new pilot training compared to 1989 , and thus much more time was spent near the reactor areas. As such, it is estimated that one to ten percent of training flights come near a reactor area, as well as 10 to 50 percent of practice exercises.

Utilizing these estimates, we can calculate that missions involving approximately 3 hours of routine patrol (out of 252), 57 hour of shipment escort (out of 57), 57 hour of training (out of 995), and 37 hours of practice exercises (out of 130) were spent over the two year $1988 / 89$ period on reactor area directed routes.

Not all of this time, however, was spent in the vicinity of a reactor. The times above include all flying time on the site, including flying time to and from the heliport in B area (near the cloverleaf). As an example, one practice exercise would include two takeoffs and landings (to drop off a team in the reactor area and then to pick them up), and a substantial flight time away from the reactor area during the team maneuvers. This exercise might take two hours, of which the take offs, landings, and flying close to the reactor areas is only a small percentage. However, the entire two hours would be categorized as a practice exercise for flight hour purposes. Another example is shipment escorts which 
begin at the heliport, escort the shipment (slowly in aircraft terms) to the reactor area and then return to the heliport. All of this time is categorized as shipment escort time, although again, only a small percentage of the time is spent near the reactor.

Considering the above, it would be conservative to assume that 50 percent of the above "reactor" flight hours actually are spent near a reactor. This would indicate a yearly near reactor flight hour total of approximately:

$$
\frac{0.5(3+57+57+37) \mathrm{hr}}{2 \mathrm{yrs}}=38.5 \text { hours per year }
$$

Statistics are available for helicopter accidents per flight hour [2]. The most complete come from military records and are summarized in Table 2.

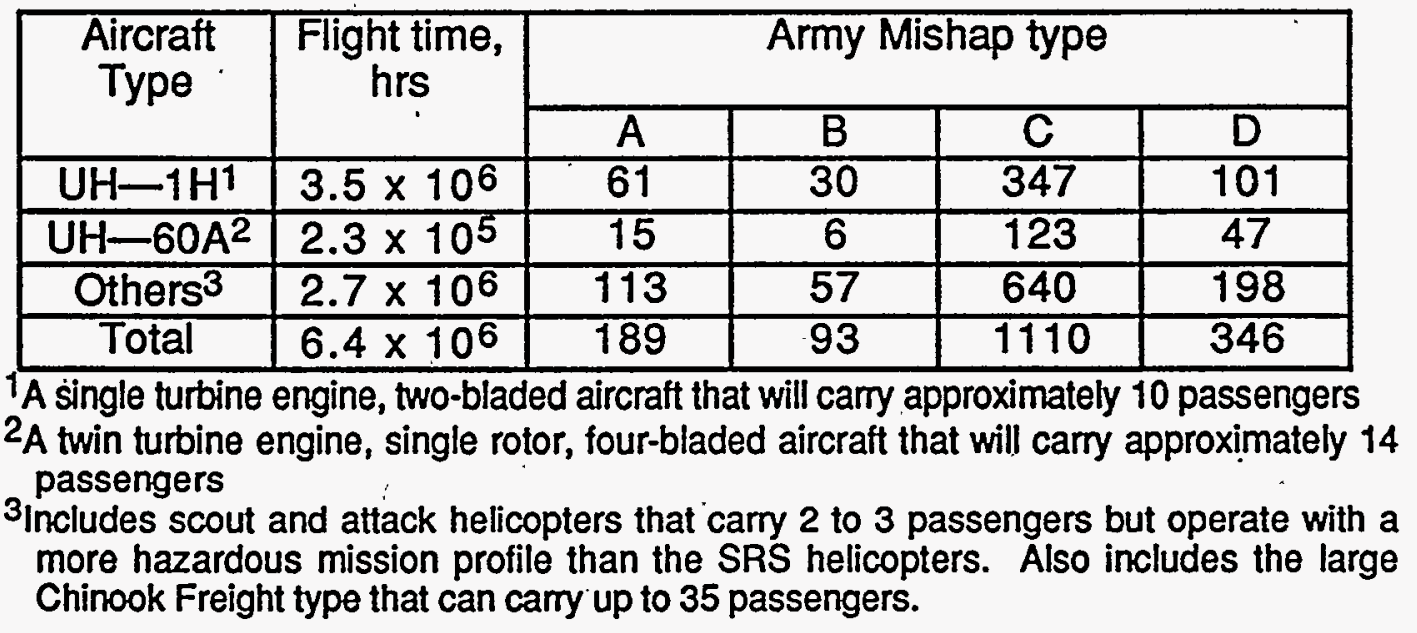

Table 2. Summary of Rotary Wing Aircraft Accidents [1]

The "Army Mishap Type" is a classification scheme which categorizes the severity of the accident in terms of dollar losses and deaths and injuries; " $A$ " being the most severe and " $D$ " the least. Only in class $A$ is damage severe enough to destroy a helicopter (damage $>\$ 500,000$ ). Class B also results in severe damage $(<\$ 500,000 ;>\$ 100,000)$. The classes $C$ and D result in less than $\$ 100,000$ in damage and no deaths or severe injuries.

Considering Table 2 and the accident classification scheme described above, we are only interested in severe accidents which could damage reactor structures or components. Thus we will consider only accident classes A and B. If we consider all helicopter types, we can calculate a frequency of severe helicopter accidents of $(189+93) / 6.4 \times 10^{6}=4.4 \times 10^{-5}$ per flight hour. However, this includes the "other" class of helicopters (Table 2) which are not equivalent in type or mission to the SRS helicopters. The UH-60A type is the most applicable to SRS helicopters, and using numbers for it, we calculate $(15+6) / 2.3 \times 10^{5}=9.1 \times 10^{-5}$ per flight hour for severe accidents, based on less flight hours. The accidents for the UH-1H type of helicopter may also be applicable to our analysis. Using the hours and accidents for both the UH-60A and UH-1H types, we obtain $3.0 \times 10^{-5}$ 
per flight hour as an accident frequency. Thus, a value of approximately $5.0 \times 10^{-5}$ per hour is a reasonable accident frequency to utilize. This translates to a frequency of approximately $5.0 \times 10^{-5}$ per $\mathrm{hr}(38.5 \mathrm{hrs})=2.0 \times 10^{-3}$ per year of having a severe helicopter accident near a reactor area.

We can also estimate the severe accident rate by considering site history. In the few years that the site has been operating, one aircraft has been lost in an accident. This occurred in September of 1985 and happened when a helicopter hit a tree during maneuvers due to not being able to pull up in time. At the time of the accident, there was only one pilot per helicopter, and helicopter power is presently somewhat larger than it was in 1985 (new, upgraded model). Thus, this type of accident is not likely to occur again. If we assume that the number of flight hours per year (not available before 1988) were similar to 1988/89 at approximately 800 per year from 1985-1989, we calculate an accident frequency of $1 / 4000=2.5 \times 10^{-4}$ per hour for the site. This number is $2 \frac{1}{2}$ times the military based frequency of $5.0 \times 10^{-5} \mathrm{per} \mathrm{hr}$, but is based on a much smaller experience base. As such, it is reasonable to assume that the military based frequency is a more accurate indication of accident rates for helicopters. Note that at a severe accident frequency of $5.0 \times 10^{-5}$ per hr, over 5 years and 4000 flight hours, a $20 \%$ chance of having one severe accident somewhere on site could have been estimated.

\section{PLANT RESPONSE TO HELICOPTER IMPACT}

The only available probabilistic analysis of the effects of an aircraft impact on plant structures is given in [5]. Two sizes of aircraft were considered (small; < $12,500 \mathrm{lb}$. and large: $>12,500 \mathrm{lb}$ ). Distributions of aircraft engine size and impact velocities were considered as functions of distance from the airport (greater or less than five miles). The results for the probability of a large or small aircraft penetrating a reinforced concrete wall of varying thickness are given in Table 3. We will assume that a helicopter may be modeled as a small aircraft $>5$ miles from an airport. This is conservative since the SRS helicopters will not be flying at speeds as high as passing aircraft, and in fact, if they are approaching a reactor area to land or for other surveillance or escort reasons, they have to ability to achieve a very slow horizontal velocity.

The main reactor building enclosing most of the reactor components is constructed of reinforced concrete of thickness

- $\quad 7 \mathrm{ft}$ from ground level to +30

- $\quad 5 \mathrm{ft}$ from +30 to +66

- $\quad 2.5 \mathrm{ft}$ from +66 to +91

- $\quad 1.5 \mathrm{ft}$ from +91 to the roof at +148

As can be seen from Table 3 , the estimated probability of a small aircraft penetrating any portion of the reactor building below elevation +91 is very close to 0.0. Above +91 it has only a 0.06 probability of penetration. These higher 


\begin{tabular}{|l|l|c|c|c|c|}
\cline { 3 - 6 } \multicolumn{2}{c|}{} & \multicolumn{4}{c|}{ Thickness of reinforced concrete } \\
\hline $\begin{array}{l}\text { Plant } \\
\text { Location }\end{array}$ & $\begin{array}{l}\text { Aircraft } \\
\text { Type }\end{array}$ & 1 foot & 1.5 feet & 2 feet & 6 feet \\
\hline \hline $\begin{array}{l}\text { S5 miles } \\
\text { from } \\
\text { airport }\end{array}$ & $\begin{array}{l}\text { Small, } \\
\leq 12,500 \\
\text { lbs. }\end{array}$ & 0.003 & 0.0 & 0.0 & 0.0 \\
\cline { 2 - 6 } & $\begin{array}{l}\text { Large, } \\
\begin{array}{l}212,500 \\
\text { lbs. }\end{array}\end{array}$ & 0.96 & 0.52 & 0.28 & 0.0 \\
\hline $\begin{array}{l}\geq 5 \text { miles } \\
\text { from } \\
\text { airport }\end{array}$ & $\begin{array}{l}\text { Small, } \\
\leq 12,500 \\
\text { lbs. }\end{array}$ & 0.28 & 0.06 & 0.01 & 0.0 \\
\cline { 2 - 6 } & $\begin{array}{l}\text { Large, } \\
212,500 \\
\text { lbs. }\end{array}$ & 1.0 & 1.0 & 0.84 & 0.32 \\
\hline
\end{tabular}

Table 3. Probability of penetration as a function of plant location and concrete thickness [5]

elevations, however, contain the drive mechanisms for the reactor safety and control rods. An aircraft penetration in this area could, therefore, cause a loss of control rod function and possibly cause some rods to be pulled out or pushed into the core. It will be shown in the next section that the frequency of small aircraft impact and penetration in this area is sufficiently negligible to not warrant further analysis.

Another entry point into reactor areas that contain safety related equipment is a concrete slab cover over a heat exchanger. There are six of these covers over the heat exchanger bay, each directly above necessary reactor equipment and exposed from above in the reactor yard (they are used to remove heat exchangers for replacement). These are multi-piece slabs which are approximately $19 \mathrm{ft}$. by $36 \mathrm{ft}$. by $3.5 \mathrm{ft}$ thick. Table 3 shows that for this thickness of reinforced concrete, the probability of penetration is negligible. The slabs are not, however, single pieces of reinforced concrete. It will be shown in the next section that an analysis of these slabs is not necessary due to the low frequency of impact on them.

Another possible vulnerability of the reactor systems to aircraft impact is the cooling water pumps and headers. The cooling water pumps and the headers (CW-1 and CW-2) that they serve are located in the 190 building adjacent to the 186 cooling water basin. This building contains the two trains of 5 pumps each which provide cooling water to the two cooling water headers. The 190 building is not blast resistant as is the reactor building and is basically constructed of transite over steel frames. It would therefore provide only minimal resistance to an aircraft impact.

The cooling water pumps themselves are not essential to reactor safety. Upon loss of the pumps, the reactor would scram due to low secondary flow, and gravity feed through the headers would be established. Either header can provide 
enough flow by gravity feed to cool a shut down reactor. However, integrity of the headers themselves must be maintained to establish gravity feed. Near the middle of the 190 building, the two headers are within a few feet of each other before exiting the building a few hundred feet apart. At this point, an aircraft impact may breach both headers and cause a total loss of secondary cooling flow to the reactor. The process water system would also be disabled after some time due to loss of cooling water flow to the AC motors and the DC diesels. The ECS system would still be available, however, through line CW-39 and the booster and emergency pumps. It will be shown in the next section that the frequency of small aircraft impact in this area is sufficiently negligible to not warrant further analysis.

Impact of a small aircraft in one of the 151-1 or 151-2 transformer yards may have the effect of degrading the offsite $A C$ power to the reactor, but not totally removing it (the 151-1 and 151-2 yards are many hundreds of feet apart). Some systems cannot be powered if one of the 151 yards are disabled (e.g., process water AC motors can only be run off of one of the yards), but redundant power systems (e.g., the process water DC motors) are available. Thus, loss of offsite power without other failures is not a core damage scenario and will not be analyzed further.

A helicopter impact may also damage the diesel intake and exhaust stacks for the diesels in the 108-1 or 108-2 buildings. However, as these are on opposite sides of the building, both would not be damaged by a single impact. The effect of damaging all of the intakes on one side would be to remove DC power from three of the process water DC motors. However, this impact cannot concurrently remove AC power (The transformer yard is hundreds of feet away), and thus the AC motors will still be available. Thus, this scenario only marginally impacts reactor operation and has no reactor safety implication.

The assembly area of the 105 building is also not a reinforced concrete structure. However, no safety related reactor equipment is located in this area. If a helicopter were to penetrate the roof here, the possibility of criticality concerns might exist, but the tendency would be to disperse the fuel assembly debris and not to concentrate it. Also, if a fire occurred due to this impact (possible large due to the helicopter fuel load) the effects would be confined to the assembly area due to the lack of a path for the fire hot gases and smoke into the rest of the 105 building-there will be a ready made escape path for these gases and smoke out the hole that the helicopter has just make. Thus, an impact in the assembly area, while possibly causing a significant monetary loss, is not a reactor safety concern.

\section{FREQUENCY OF HEIICOPTER IMPACT ON K-REACTOR STRUCTURES OR SYSTEMS}

The frequency of impact of aircraft into K-reactor structures or systems is a function of the frequency of helicopter crashes near a reactor area, the geometry of the aircraft path compared to the K-reactor site, and the probability of penetrating the reactor building structure. 
To estimate the actual frequency of helicopter impact into K-reactor structures, we will proceed by utilizing the crash frequency per year near reactor areas of $2.0 \times 10^{-3}$ from Section 2 and a value for the effective area of the main reactor building of 0.0065 square miles [6] based on a $45^{\circ}$ angle of approach by the incoming aircraft. Reference 6 was an earlier aircraft risk analysis for the SRS reactors, but in 1973 when it was performed, the area over the SRS was restricted airspace and only 100 or so unauthorized flights per year flew over the SRS, and there were no on site aircraft.

We assume that a helicopter flying in the "vicinity" of a reactor area is flying within a one square mile area around the reactor. This means that if we assume that a helicopter would fly randomly within this square mile and would have a severe accident at a rate of $2.0 \times 10^{-3}$ per year, then the frequency of that severe accident causing the helicopter to impact the reactor building is approximately $2.0 \times 10^{-3}(0.0065)=1.3 \times 10^{-5}$ per year.' This number is obviously sensitive to the flying area assumed (i.e. $1 \mathrm{mile}^{2}$ ), but we consider it to be conservative because:

1. Helicopters do not normally fly over the reactor buildings [4], and as such are more likely to be away from the reactor if an accident were to happen (as opposed to the assumption of uniform random aircraft placement assumed above), and

2. As discussed in [2], a pilot is expected to be able to maneuver the helicopter four feet horizontally for every one foot vertical drop with the loss of both engines. Thus, even if a helicopter were to lose power only 500 feet directly above a building, he would be expected to be able to maneuver up to 2000 feet away before striking the ground.

The effective area for the reactor building of $0.0065 \mathrm{mi}^{2}$ encompasses the entire building structure. As discussed in Section 1.3, only the top portion of the reactor building is really vulnerable to impact from small aircraft. As shown in Figure 1, the effective area for the reactor structure above elevation +91 is $9.4 \times 10^{-5}$ square miles, which gives an effective frequency of $2.0 \times 10^{-3}\left(9.4 \times 10^{-5}\right)=1.9 \times 10^{-7}$ helicopter crashes into the upper reactor structure per year. We may also factor in the $\mathbf{0 . 0 6}$ probability of a small aircraft penetrating the concrete structure to arrive at a negligible scenario probability of $1.1 \times 10^{-8}$ crashes per year which penetrate the upper reactor building.

Similarly, we know that the effective area of all six of the heat exchanger cover slabs is $(6)(19)(36)=4104 \mathrm{ft}^{2}$, or $1.5 \times 10^{-4} \mathrm{mi}^{2}$. This gives $2.0 \times 10^{-3}\left(1.5 \times 10^{-4}\right)=$ $3.0 \times 10^{-7}$ helicopter crashes into the heat exchanger bay slabs per year. This in itself is negligible, but the probability of penetration of the slab is still unknown. If we assume that the slab only affords as much resistance to penetration as a one foot thick slab of reinforced concrete, we arrive at $3.0 \times 10^{-7}(0.28)=8.4 \times 10^{-8} \mathrm{per}$ year for the frequency of penetration of a heat exchanger cover slab.

A similar calculation is performed in the case of the 190 building housing the secondary cooling pumps. The entire building is on the order of $250 \mathrm{ft} \times 50 \mathrm{ft}=$ 


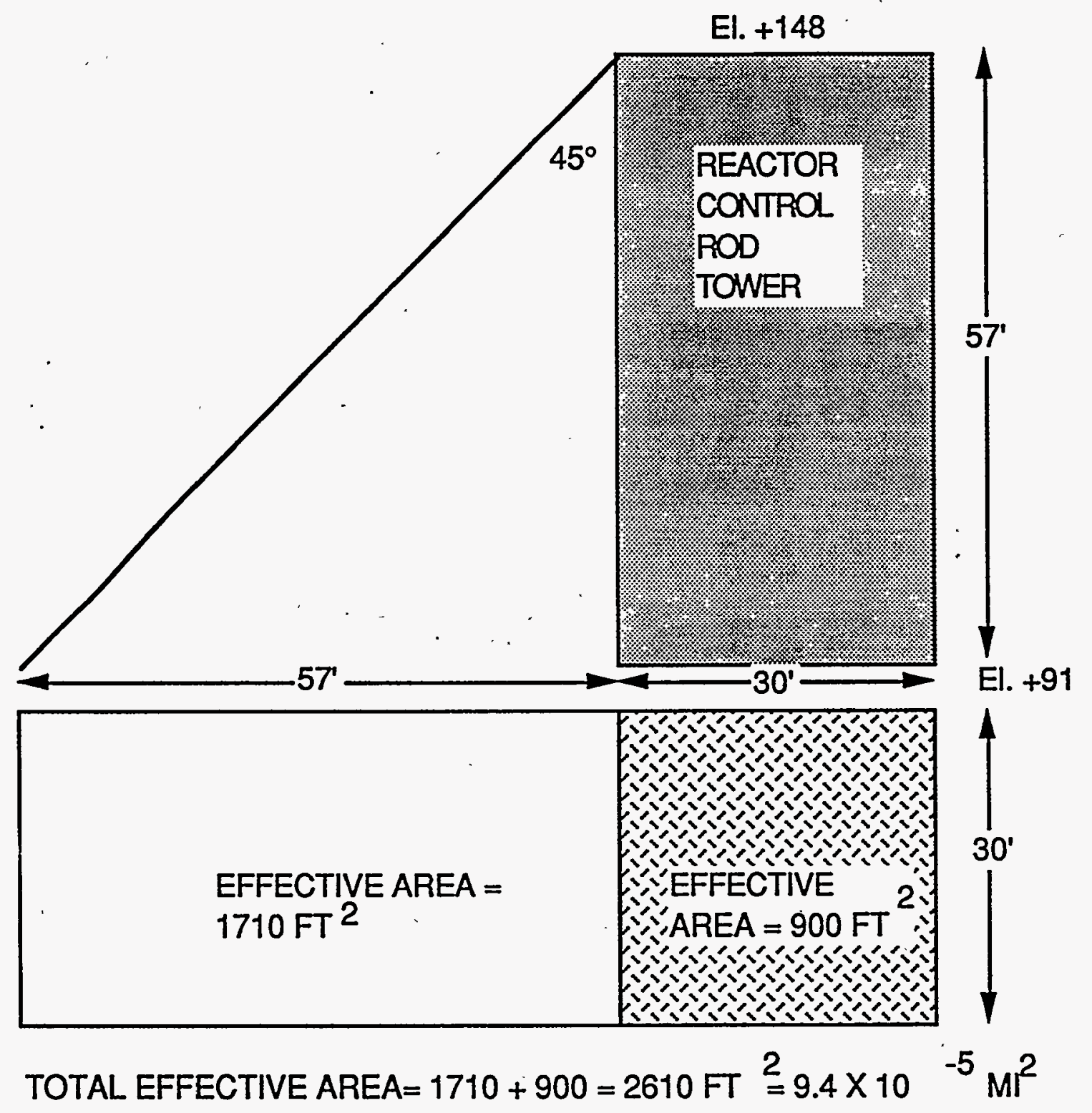

Figure 1. Effective impact area for the K-reactor actuator tower

$4.5 \times 10^{-4}$ square miles. It is situated in such a way that an helicopter would almost have to come straight down on top of it (it is shielded by the 186 basin on one side and the reactor building shields the other; in addition, it is only 15 or so feet above ground) in order to cause damage. Also, the area which an helicopter would have to impact to breach both cooling water headers is much smaller than the entire 190 building, on the order of $20 \times 20$ feet $\left(1.4 \times 10^{-5}\right.$ square miles), so that a limiting frequency for this scenario would be $2.0 \times 10^{-3} \mathrm{X} 1.4 \times 10^{-5}=2.9 \times 10^{-8}$ per year, a frequency which is also negligible. This frequency also does not take into account the probability of actually breaching both of the headers upon impact. This probability is something less than 1.0.

As the frequency of helicopter reactor impacts in general is very low and the frequency of helicopter crash generated accidents has been shown to be negligible 
(no other credible scenarios for a small helicopter impact causing reactor damage were identified), helicopter impacts into K-reactor buildings or systems are seen to be a negligible contributor to risk.

\section{REFERENCES}

1 Brandyberry, M.D., Wingo, H.E., SRS PRA of Reactor Operations-Level 1 External Events, WSRC-RP-89-733

2 Security Helicopter Operations Safety Analysis Report, Wackenhut services, Inc. (WSI), December 12, 1984.

3 U.S. Nuclear Regulatory Commission Standard Review Plan, NUREG-0800, July 1981.

4 Private communication, J. Snow, WSI Aviation Manager.

5 Chelapati, C.V., Kennedy; R.P., "Probabilistic Assessment of Aircraft Hazard for Nuclear Power Plants," Nuclear Engineering and Design, 19, pp. 333-364, 1972.

6 Nomm, E., Probability of Aircraft Crash at SRP, DPST-73-402, July 1973. 